$\begin{array}{lllllllllllll}\text { A C T A H E M C A S C A N D I N A V I C A } & \text { (1953) } & 469-480\end{array}$

\title{
On the Application of the Mass Action Law to Cation Exchange Equilibria
}

\author{
ST URE FRON A US
}

Department of Inorganic and Physical Chemistry, Chemical Institute, University of Lund, Lund, Sweden

D uring the last ten years several investigations concerning the applicability of the mass action law to cation exchange equilibria especially on synthetic organic exchangers have been reported in the literature. Some of the investigators have found that the mass law product (which we will call $k$ here analogous to the notations below) is very nearly a mass action constant. Thus Boyd, Schubert, and Adamson ${ }^{1}$ studied the exchange $\mathrm{Na}^{+}-\mathrm{H}^{+}$on Amberlite IR-1 and arrived at the result that $k$ was approximately constant even at great variations of the mole fractions of the resin phase. A similar result was obtained by Kressman and Kitchener ${ }^{2}$ at a great number of exchanges.

Other authors, however, have found that sometimes the mass law product $k$ is rather dependent upon the mole fractions of the resin phase. Such results are for instance reported by Samuelson ${ }^{3}$, and Högfeldt, Ekedahl, and Sillén 4. From the three last-mentioned authors' investigation of the exchange $\mathrm{Ag}^{+}-\mathrm{H}^{+}$ on Dowex 50 it is evident that at mole fractions $<0.03$ of silver in the resin phase $k$ rapidly increases with decreasing silver load, while at mole fractions between 0.03 and $0.40 \mathrm{k}$ is approximately constant.

In three previous papers by the present author (Fronæus ${ }^{5-7}$ ) concerning the investigation of complex equilibria by the use of cation exchangers, the mass law products $k_{0}$ and $k_{1}$ of the exchange equilibria: $\mathrm{M}^{2+}-\mathrm{Na}^{+}$and $\mathrm{MA}^{+}-\mathrm{Na}^{+}\left(\mathrm{M}^{2+}=\mathrm{Cu}^{2+}, \mathrm{Ni}^{2+} ; \mathrm{A}^{-}=\mathrm{Ac}^{-}, \mathrm{SCN}^{-}\right)$on Amberlite IR-105 were also studied. At these investigations the following facts were established.

1. For both cupric and nickel ions and at $\mathrm{p}\left[\mathrm{H}^{+}\right] \approx 5$ the mass law product $k_{0}$ increased rapidly with decreasing values of the cupric respective nickel load $\mathrm{C}_{\mathrm{MR}}$ on the cation exchanger, though $\mathrm{C}_{\mathrm{MR}}$ was kept very low in comparison with the exchange capacity of the ion exchanger, and the ionic strength of the Acta Chem. Scand. 7 (1953) No. 3 
outer solution was kept constant $(I=1 \mathrm{C})$ by addition of sodium perchlorate. This behaviour is very surprising, for under the conditions mentioned the resin phase is to be regarded as a sodium sulphonate solution of high concentration, and at minute exchanges of sodium ions for cupric or nickel ions we should expect the rational activity. coefficients in both phases not to be changed appreciably and thus $k_{0}$ to be a constant.

2. At the same value of $\mathrm{p}\left[\mathrm{H}^{+}\right]$and with $\mathrm{A}^{-}=$acetate ion it was proved that at a fixed value of $\mathrm{C}_{\mathrm{MR}}$ both $k_{0}$ and $k_{1}$ were constant and independent of the distribution of $\mathrm{C}_{\mathrm{MR}}$ between $\mathrm{M}^{2+}$ and $\mathrm{MA}^{+}$. Thus it seems that at small $\mathrm{C}_{\mathrm{MR}}$ these cations in spite of their different charges had the same influence on the stoichiometric activity coefficients within the resin phase.

3. The measurements on the nickel thiocyanate system showed that at $\mathrm{p}\left[\mathrm{H}^{+}\right] \approx 3 k_{0}$ and $k_{1}$ were but slightly dependent upon the nickel load $\mathrm{C}_{\mathrm{MR}}$.

These findings indicate that the variations of the stoichiometric activity coefficients must sure be caused by the presence of small amounts of coordinating groups, attached to the resin used and operating at $\mathrm{p}\left[\mathrm{H}^{+}\right]=5$ but blocked up at $\mathrm{p}\left[\mathrm{H}^{+}\right]=3$. It will be shown below that in this way the variations of $k_{0}$ can be perfectly explained.

To test the theory in the present investigation the exchange $\mathrm{Cu}^{2+}-\mathrm{Na}^{+}$ at different $\mathrm{p}\left[\mathrm{H}^{+}\right]$-values has been studied on Amberlite IR-105 and Dowex 50.

\section{THEORETICAL TREATMENT}

We presuppose that the solutions contain a divalent cation $\mathrm{M}^{2+}$ and a monovalent anion $\mathrm{A}^{-}$forming mononuclear complexes. Then $\mathrm{M}^{2+}$ and the first complex $\mathrm{MA}^{+}$can be taken up by the cation exchanger in the sodium form. Furthermore we presuppose that the exchanger contains small amounts of a group $\mathrm{B}^{-}$, attached to the resin and capable of forming complexes with both $\mathrm{M}^{2+}$ and $\mathrm{MA}^{+}$. Thus we have within the exchanger: $\mathrm{M}_{\mathbf{R}}^{2+}, \mathrm{MA}_{\mathbf{R}}^{+}, \mathrm{MB}_{\mathbf{R}}^{+}$, and $\mathrm{MAB}_{\mathrm{R}}$. (The index $\mathrm{R}$ only marks the resin phase.)

Now we apply the mass law to the following exchange equilibria between the "free" ions:

and get:

$$
\begin{aligned}
& \mathrm{M}^{2+}+2 \mathrm{Na}_{\mathrm{R}}^{+} \rightleftharpoons \mathrm{M}_{\mathrm{R}}^{2+}+2 \mathrm{Na}^{+} \\
& \mathrm{MA}^{+}+\mathrm{Na}_{\mathrm{R}}^{+} \rightleftharpoons \mathrm{MA}_{\mathrm{R}}^{+}+\mathrm{Na}^{+}
\end{aligned}
$$

$$
\frac{\left[\mathrm{M}^{2+}\right]_{\mathrm{R}}}{\left[\mathrm{M}^{2+}\right]}=k_{0}^{\prime} \cdot \frac{\left[\mathrm{Na}^{+}\right]_{\mathrm{R}}^{2}}{\left[\mathrm{Na}^{+}\right]^{2}} ; \frac{\left[\mathrm{MA}^{+}\right]_{\mathrm{R}}}{\left[\mathrm{MA}^{+}\right]}=k_{1}^{\prime} \cdot \frac{\left[\mathrm{Na}^{+}\right]_{\mathrm{R}}}{\left[\mathrm{Na}^{+}\right]}
$$

In the previous papers ${ }^{5-7}$ we have not distinguished between $M_{R}^{2+}$ and $M^{2} B_{R}^{+}$ and between $\mathrm{MA}_{\mathrm{R}}^{+}$and $\mathrm{MAB}_{\mathrm{R}}$. Thus if in eq. (1) $\left[\mathrm{M}^{2+}\right]_{R}$ is exchanged for 
$\left[\mathrm{M}^{2+}\right]_{\mathrm{R}}+\left[\mathrm{MB}^{+}\right]_{\mathrm{R}}$, we get the quantity $k_{0}$ instead of $k_{0}^{\prime}$ (cf. Fronaeus ${ }^{5, \mathrm{p} .861}$ ). On the other hand, if we define a complexity constant $\beta$ of the complex $\mathrm{MB}^{+}$ by the relation $\left[\mathrm{MB}^{+}\right]_{\mathrm{R}}=\beta \cdot\left[\mathrm{M}^{2+}\right]_{\mathrm{R}} \cdot\left[\mathrm{B}^{-}\right]_{\mathrm{R}}$ we have: $\left[\mathrm{M}^{2+}\right]_{\mathrm{R}}+\left[\mathrm{MB}^{+}\right]_{\mathrm{R}}$ $=\left[\mathrm{M}^{2+}\right]_{\mathrm{R}}\left(1+\beta\left[\mathrm{B}^{-}\right]_{\mathrm{R}}\right)$ and then the relation between $k_{0}^{\prime}$ and $k_{0}$ is obtained:

$$
k_{0}=k_{0}^{\prime}\left(1+\beta\left[\mathrm{B}^{-}\right]_{\mathrm{R}}\right)
$$

Analogously we define a complexity constant $\gamma$ of $\mathrm{MAB}_{\mathrm{R}}:[\mathrm{MAB}]_{\mathrm{R}}=\gamma$ - $\left[\mathrm{MA}^{+}\right]_{\mathrm{R}} \cdot\left[\mathrm{B}^{-}\right]_{\mathrm{R}}$ and get the relation between $k_{1}^{\prime}$ and the previous mass law product $k_{1}$ :

$$
k_{1}=k_{1}^{\prime}\left(1+\gamma\left[\mathrm{B}^{-}\right]_{\mathrm{R}}\right)
$$

For the total concentrations $\mathrm{C}_{\mathrm{BR}}$ and $\mathrm{C}_{\mathrm{MR}}$ in the resin phase we have the following expressions:

$$
\begin{aligned}
& \mathrm{C}_{\mathrm{BR}}=[\mathrm{HB}]_{\mathrm{R}}+\left[\mathrm{B}^{-}\right]_{\mathrm{R}}+\left[\mathrm{MB}^{+}\right]_{\mathrm{R}}+[\mathrm{MAB}]_{\mathrm{R}} \\
& \mathrm{C}_{\mathrm{MR}}=\left[\mathrm{M}^{2+}\right]_{\mathrm{R}}+\left[\mathrm{MA}^{+}\right]_{\mathrm{R}}+\left[\mathrm{MB}^{+}\right]_{\mathrm{R}}+[\mathrm{MAB}]_{\mathrm{R}}
\end{aligned}
$$

Let us denote by $k_{c}$ the dissociation constant of the acid HB corresponding to the group $\mathrm{B}^{-}$. Then, using the equations of $\beta$ and $\gamma$, given above, we can transform the expressions (4) and (5) into the following ones:

$$
\begin{aligned}
& \mathrm{C}_{\mathrm{BR}}-\left(1+\left[\mathrm{H}^{+}\right]_{\mathrm{R}_{i}^{\mathbf{D}}} \cdot k_{c}^{-1}\right) \cdot\left[\mathrm{B}^{-}\right]_{\mathrm{R}}=\left[\mathrm{B}^{-}\right]_{\mathrm{R}}\left(\beta\left[\mathrm{M}^{2+}\right]_{\mathrm{R}}+\gamma\left[\mathrm{MA}^{+}\right]_{\mathrm{R}}\right) \\
& \mathrm{C}_{\mathrm{MR}}=\left[\mathrm{M}^{2+}\right]_{\mathrm{R}}\left(1+\beta\left[\mathrm{B}^{-}\right]_{\mathrm{R}}\right)+\left[\mathrm{MA}^{+}\right]_{\mathrm{R}}\left(1+\gamma\left[\mathrm{B}^{-}\right]_{\mathrm{R}}\right)
\end{aligned}
$$

Under certain conditions it is possible to obtain very simple relations between the load $\mathrm{C}_{\mathrm{MR}}$ on the exchanger and the mass law products. Thus it is suitable to distinguish between three different cases.

a) The load $\mathrm{C}_{\mathrm{MR}}$ is kept so small that $\mathrm{C}_{\mathrm{MR}}<\mathrm{C}_{\mathrm{BR}}$, and the complexity constants $\beta$ and $\gamma$ have great values. Then $\left[\mathrm{M}^{2+}\right]_{\mathrm{R}}$ and $\left[\mathrm{MA}^{+}\right]_{\mathrm{R}}$ can be neglected in eq. (5) and we get: $\mathrm{C}_{\mathrm{BR}}-\left(1+\left[\mathrm{H}^{+}\right]_{\mathrm{R}} \cdot k_{c}^{-1}\right) \cdot\left[\mathrm{B}^{-}\right]_{\mathrm{R}}=\mathrm{C}_{\mathrm{MR}}$ and the expression for $k_{0}$ becomes:

$$
k_{0}=k_{0}^{\prime}\left(1+\frac{\beta\left(\mathrm{C}_{\mathrm{BR}}-\mathrm{C}_{\mathrm{MR}}\right)}{1+\left[\mathrm{H}^{+}\right]_{\mathrm{R}} \cdot k_{c}^{-1}}\right)
$$

For $k_{1}$ we get a quite analogous expression from eq. (3).

If $\mathrm{C}_{\mathrm{MR}}$ is kept very small in comparison with the exchange capacity, and the ionic strength of the solutions is constant, the rational activity coefficients involved in $k_{0}^{\prime}$ can be presumed to be nearly constant. The value of $\mathrm{C}_{\mathrm{BR}}$ is fixed for a given exchanger, and we see that at a constant value of $\left[\mathrm{H}^{+}\right]$ (and thus of $\left[\mathrm{H}^{+}\right]_{\mathrm{R}}$ ) $k_{0}$ is a linearly decreasing function of $\mathrm{C}_{\mathrm{MR}}$ solely.

Acta Chem. Scand. 7 (1953) No. 3 
b) $\mathrm{C}_{\mathrm{MR}}$ is of about the same magnitude as $\mathrm{C}_{\mathrm{BR}}$, or $\beta$ and $\gamma$ have not great values. Then we can get simple relations only if $\beta \approx \gamma$. In that case the following equation is at once obtained from eq. (6) and (7):

$$
\frac{\mathrm{C}_{\mathrm{BR}}-\left(1+\left[\mathrm{H}^{+}\right]_{\mathrm{R}} \cdot k_{c}^{-1}\right)\left[\mathrm{B}^{-}\right]_{\mathrm{R}}}{\mathrm{C}_{\mathrm{MR}}}=\frac{\beta\left[\mathrm{B}^{-}\right]_{\mathrm{R}}}{1+\beta\left[\mathrm{B}^{-}\right]_{\mathrm{R}}}
$$

From eq. (9) it is easily seen that $\left[\mathrm{B}^{-}\right]_{\mathrm{R}}$ and consequently $k_{0}$ and $k_{1}$ decrease at increasing values of $\mathrm{C}_{\mathrm{MR}}$.

A possible complex formation between $\mathrm{M}^{2+}$ and sulphonate groups cannot cause a perceptible dependence of $k_{0}$ and $k_{1}$ upon $\mathrm{C}_{\mathrm{MR}}$, for in this case $\left(\mathrm{B}^{-}=-\mathrm{SO}_{3}^{-}\right) \mathrm{C}_{\mathrm{BR}}$ has a great value, equal to the exchange capacity, and thus $\mathrm{C}_{\mathrm{MR}}\left\langle\left\langle\mathrm{C}_{\mathrm{BR}}\right.\right.$ and $\left[\mathrm{B}^{-}\right]_{\mathrm{R}} \approx \mathrm{C}_{\mathrm{BR}} /\left(1+\left[\mathrm{H}^{+}\right]_{\mathrm{R}} \cdot k_{c}^{-1}\right)$. Besides, if the ion $\mathrm{M}^{2+}$ in reality is not "free" but is present as $\mathrm{MSO}_{3}^{+}-$, and we have a second fixed coordinating group $\mathrm{B}^{-}$, it is easily seen that our eq. (8) and (9) are still valid if $k_{0}^{\prime}$ relates to $\mathrm{MSO}_{3}^{+}$. . In this case the fulfilment of the condition $\beta \approx \gamma$ for the validity of eq. (9) is plausible, for $\mathrm{MSO}_{3}^{+}$- and $\mathrm{MA}^{+}$are of the same type with equal net charge and we should expect them to have about the same affinity for $\mathrm{B}^{-}$, provided there is no steric hindrance to the coordination of the two fixed groups to the same central ion.

c) $\mathrm{C}_{\mathrm{MR}}>\mathrm{C}_{\mathrm{BR}}$ and $\beta \approx \gamma$ has a great value. Then in eq. (4) we can neglect $\left[\mathrm{B}^{-}\right]_{R}$ and $[\mathrm{HB}]_{R}$ (at not very low $\mathrm{p}\left[\mathrm{H}^{+}\right]$-values). From eq. (9) we obtain $\mathrm{C}_{\mathrm{BR}} /\left(\mathrm{C}_{\mathrm{MR}}-\mathrm{C}_{\mathrm{BR}}\right)=\beta\left[\mathrm{B}^{-}\right]_{\mathrm{R}}$ and:

$$
\frac{k_{0}}{k_{0}^{\prime}}=\frac{k_{1}}{k_{1}^{\prime}}=1+\frac{\mathrm{C}_{\mathrm{BR}}}{\mathrm{C}_{\mathrm{MR}}-\mathrm{C}_{\mathrm{BR}}}
$$

As a summary of the different cases we can say that at $\mathrm{p}\left[\mathrm{H}^{+}\right]$-values not far away from $\mathrm{p} k_{c}$ and at a great value of $\beta \approx \gamma$ the relation between the mass law products and $\mathrm{C}_{\mathrm{MR}}$ can be represented by a curve of the type given in Fig. 1. At decreasing values of $\beta \approx \gamma$ the rectilinear part will be less pronounced. Of course $\mathrm{C}_{\mathrm{MR}}$ must be much smaller than the exchange capacity, otherwise variations in the rational activity coefficients will occur.

In all the cases discussed it is valid that at decreasing $\mathrm{p}\left[\mathrm{H}^{+}\right]$-values $[\mathrm{HB}]_{R} \rightarrow \mathrm{C}_{\mathrm{BR}}$ (that is $\left[\mathrm{B}^{-}\right]_{R} \rightarrow 0$ ) if $\mathrm{HB}$ is a weak acid. Then at sufficient low $\mathrm{p}\left[\mathrm{H}^{+}\right]$-values the dependence of $k_{0}$ and $k_{1}$ upon $\mathrm{C}_{\mathrm{MR}}$ disappears, and we obtain: $k_{0}=k_{0}^{\prime}, k_{1}=k_{1}^{\prime}$.

Finally it should be emphasized that a direct experimental determination of the relation between $k_{0}$ and $\mathrm{C}_{\mathrm{MR}}$ is possible only if no diffusible ligand $\mathrm{A}^{-}$ is present. Then all our equations for $k_{0}$ are of course valid without the restrictive condition $\beta \approx \gamma$. 


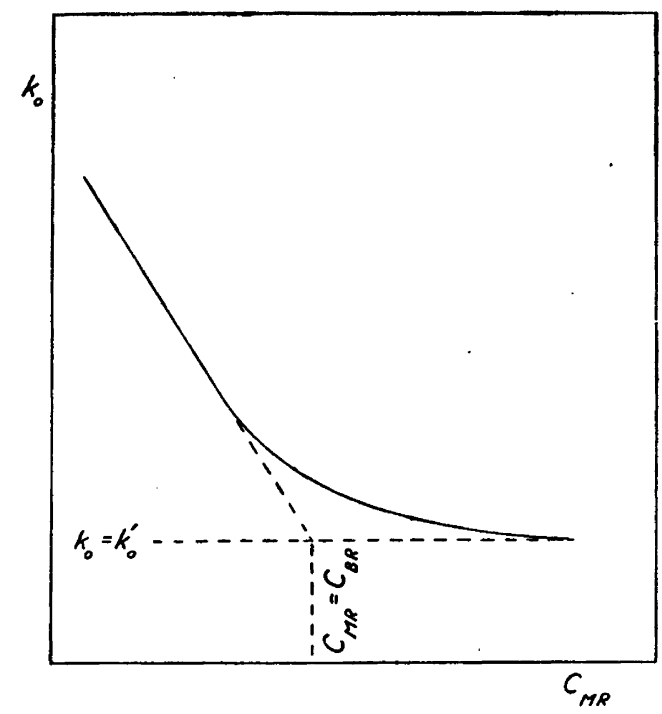

Fig. 1. The fulldrawn curve represents the predicted relation between $k_{0}$ and $C_{\mathrm{MR}}$ at a great value of $\beta \approx \gamma$.

\section{MEASUREMENTS}

Chemicals used. The cation exchangers used were Amberlite IR-105 and Dowex 50. They were transferred into the sodium forms and air-dried. Their exchange capacities were determined at $\left.\mathrm{p}^{+} \mathrm{H}^{+}\right]=5.0$ in the manner described in a previous paper ${ }^{7}$. The other chemicals were prepared as before ${ }^{8}$.

For the determination of corresponding values of $k_{0}$ and $\mathrm{C}_{\mathrm{MR}} v(=0.01)$

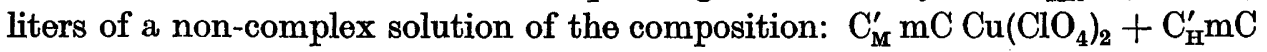
$\mathrm{HClO}_{4}+\left(1000-\mathrm{C}_{\mathrm{H}}^{\prime}-3 \mathrm{C}_{\mathrm{M}}^{\prime}\right) \quad \mathrm{mC} \mathrm{NaClO}_{4}$ were shaken at $20.0^{\circ} \mathrm{C}$ with $\mathrm{m}$ $(=0.4)$ grams of the dried exchanger, until an exchange equilibrium was attained. Then the resin was separated and the equilibrium copper concentration $\mathrm{C}_{\mathrm{M}}$ and $\mathrm{p}\left[\mathrm{H}^{+}\right]$of the solution were measured. The copper determination was performed extinctiometrically with the use of ammonia at the wave length $6200 \AA$ or for the lowest $\mathrm{C}_{\mathrm{M}}$-values with the use of dithizone (cf. Liebhafsky and Winslow ${ }^{9}$ ) at $5080 \AA$. As to experimental details at the determination the reader is referred to a previous paper ${ }^{5}$.

The value of $\mathrm{p}\left[\mathrm{H}^{+}\right]$was measured potentiometrically with the quinhydrone electrode. At these measurements the reference electrode contained perchloric acid and sodium perchlorate.

Acta Chem. Scand. 7 (1953) No. 3 
When the solutions contain no ligand $\mathrm{A}^{-}$, we have $\mathrm{C}_{\mathrm{M}}=\left[\mathrm{M}^{2+}\right]$, and the expression (5) takes the form: $\mathrm{C}_{\mathrm{MR}}=\left[\mathrm{M}^{2+}\right]_{\mathrm{R}}+\left[\mathrm{MB}^{+}\right]_{\mathrm{R}}$. Then according to our definition of $k_{0}$ we have:

$$
\frac{\mathrm{C}_{\mathrm{MR}}}{\mathrm{C}_{\mathrm{M}}}=k_{0} \frac{\left[\mathrm{Na}^{+}\right]_{\mathrm{R}}^{2}}{\left[\mathrm{Na}^{+}\right]^{2}}
$$

$\mathrm{C}_{\mathrm{MR}}$ is obtained from the relation: $\mathrm{C}_{\mathrm{MR}}=\frac{v}{m}\left(\mathrm{C}_{\mathrm{M}}^{\prime}-\mathrm{C}_{\mathrm{M}} \cdot \delta\right)$. The value of the factor $\delta$, depending upon the swelling of the resins in the solutions, was measured on a solution with $\mathrm{C}_{M}^{\prime}=\mathrm{C}_{\mathrm{H}}^{\prime}=0$. Its total salt concentrations before and after the treatment with the exchanger were determined in the ordinary way with a cation exchanger column in the hydrogen form. The quotient between these concentrations gave us the value of $\delta$. It was 0.985 for Amberlite IR-105 and 0.990 for Dowex 50 at the value of $v / m$ used.

For $\left[\mathrm{Na}^{+}\right]$and $\left[\mathrm{Na}^{+}\right]_{\mathbf{R}}$ the following expressions are valid:

$$
\begin{aligned}
& {\left[\mathrm{Na}^{+}\right]=\frac{1000-\mathrm{C}_{\mathrm{M}}^{\prime}}{\delta}-2 \mathrm{C}_{\mathrm{M}}-\left[\mathrm{H}^{+}\right] \mathrm{mC}} \\
& {\left[\mathrm{Na}^{+}\right]_{\mathrm{R}}=a-2 \mathrm{C}_{\mathrm{MR}}-\left[\mathrm{H}^{+}\right]_{\mathrm{R}} \text { mmoles/gram }}
\end{aligned}
$$

At the calculation of $\left[\mathrm{Na}^{+}\right] /\left[\mathrm{Na}^{+}\right]_{\mathrm{R}}$ the correction terms $\left[\mathrm{H}^{+}\right]$and $\left[\mathrm{H}^{+}\right]_{\mathrm{R}}$ can be neglected at $\mathrm{p}\left[\mathrm{H}^{+}\right]$-values $\geqq 2$. $a$ is the exchange capacity (= sulphonate ion concentration) of the dried exchanger in the sodium form and has the values 2.31 (Amberlite IR-105) and 3.80 (Dowex 50) meq.per gram.

Table 1. Determination of the mass law product $k_{0}$ for the exchange $\mathrm{Cu}^{2+}-\mathrm{Na}^{+}$on Amberlite IR-105 at different values of $p\left[H^{+}\right]$and $C_{\mathrm{MR}}$.

\begin{tabular}{|c|c|c|c|c|}
\hline $\mathrm{p}\left[\mathrm{H}^{+}\right]$ & $\begin{array}{c}\mathrm{C}_{\mathrm{M}}^{\prime} \\
\mathrm{mC}\end{array}$ & $\begin{array}{c}C_{\mathrm{M}} \\
\mathrm{mC}\end{array}$ & $\begin{array}{c}C_{\mathrm{MR}} \cdot 10^{2} \\
\mathrm{mmole} \cdot \mathrm{g}^{-1}\end{array}$ & $\begin{array}{c}k_{0} \cdot 10^{-3} \\
1^{-1} \cdot \mathrm{g}\end{array}$ \\
\hline 2.9 & 2.46 & 1.48 & & \\
2.9 & 4.98 & 3.10 & 4.83 & 3.27 \\
2.9 & 9.97 & 6.60 & 8.70 & 3.09 \\
2.9 & 15.00 & 10.33 & 12.10 & 2.75 \\
2.9 & 20.00 & 14.17 & 15.15 & 2.55 \\
& & & & 2.40 \\
2.0 & 5.01 & 3.68 & 3.48 & 1.80 \\
2.0 & 10.01 & 7.40 & 6.83 & 1.83 \\
2.0 & 15.00 & 11.18 & 10.00 & 1.82 \\
2.0 & 20.00 & 15.00 & 13.10 & 1.84 \\
\hline
\end{tabular}




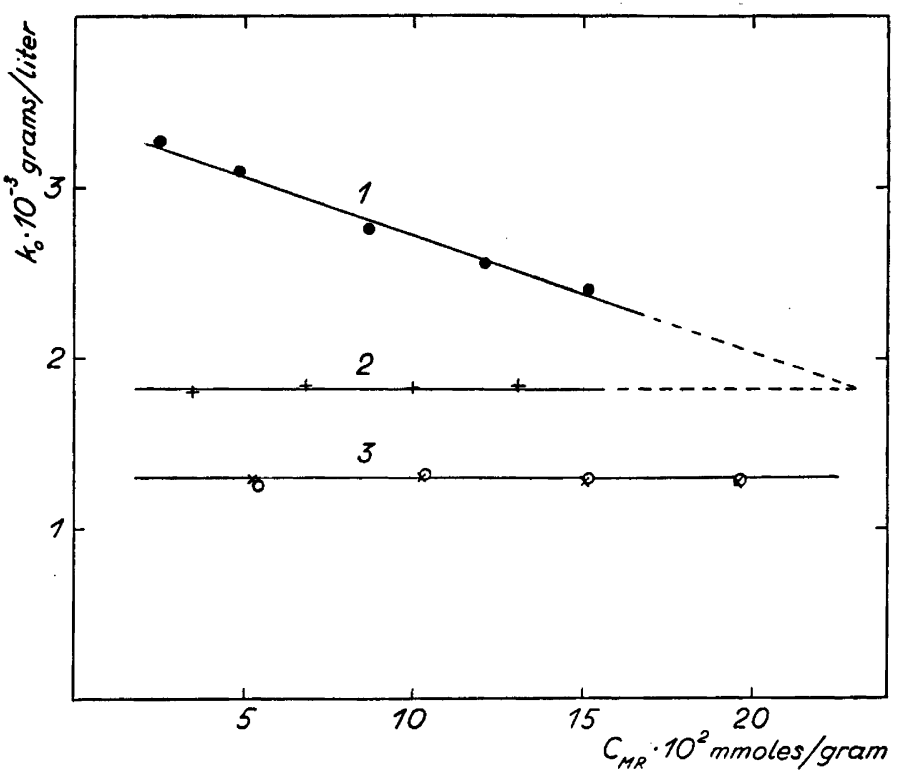

Fig. 2. The relation between $k_{0}$ and $C_{\mathrm{MR}}$ for the exchange $\mathrm{Cu}^{2+}-\mathrm{Na}^{+}$on different exchang. ers and at different $p\left[H^{+}\right]$-values.

1. and 2. Amberlite $I R-105$ at $p\left[H^{+}\right]=2.9$ and 2.0 respectively;

3. Dowex 50 at $p\left[H^{+}\right]=4.2$ (O) and $3.1(\times)$.

Table 1 contains the values obtained at the measurements of the exchange $\mathrm{Cu}^{2+}-\mathrm{Na}^{+}$on Amberlite IR-105 at $\mathrm{p}\left[\mathrm{H}^{+}\right]=2.9$ and 2.0. From Fig. 2 it is evident that at $\mathrm{p}\left[\mathrm{H}^{+}\right]=2.9 k_{0}$ decreases approximately linearly with increasing $\mathrm{C}_{\mathrm{MR}}$ at these low values of the cupric load. From this we conclude that $\beta$ has a rather great value and that $\mathrm{C}_{\mathrm{MR}}<\mathrm{C}_{\mathrm{BR}}$ (case $a$ ) above). At $\mathrm{p}\left[\mathrm{H}^{+}\right]=\mathbf{2 . 0}$ on the other hand $k_{0}$ is independent of $\mathrm{C}_{\mathrm{MR}}$. At this lower value of $\mathrm{p}\left[\mathrm{H}^{+}\right]$the groups $\mathrm{B}^{-}$evidently are blocked up by hydrogen ions, and thus we have here $k_{0}=k_{0}^{\prime}=1.82 \cdot 10^{3}$ grams/liter. Eq. (8) indicates that if the straight lines 1 and 2 in Fig. 2 are extrapolated, the $\mathrm{C}_{M R}$-value of the intersection gives the value of the concentration $\mathrm{C}_{\mathrm{BR}}$ (cf. Fig. 1). Thus we get here $\mathrm{C}_{\mathrm{BR}}=\mathbf{0 . 2 3}$ mmoles/gram.

In Fig. 3 the connection between $k_{0}$ and $\mathrm{C}_{\mathrm{MR}}$ at $\mathrm{p}\left[\mathrm{H}^{+}\right]=4.9$ is represented. The values have been calculated from distribution measuremenets in a previous paper ${ }^{5}$. The measurements, that were performed at varying concentrations of an acetate buffer, have been extrapolated to acetate-free solutions. At $\mathrm{p}\left[\mathrm{H}^{+}\right]=4.9$ the dependence of $k_{0}$ upon $\mathrm{C}_{\mathrm{MR}}$ is much greater than at $\mathrm{p}\left[\mathrm{H}^{+}\right]$ Acta Chem. Scand. 7 (1953) No. 3 


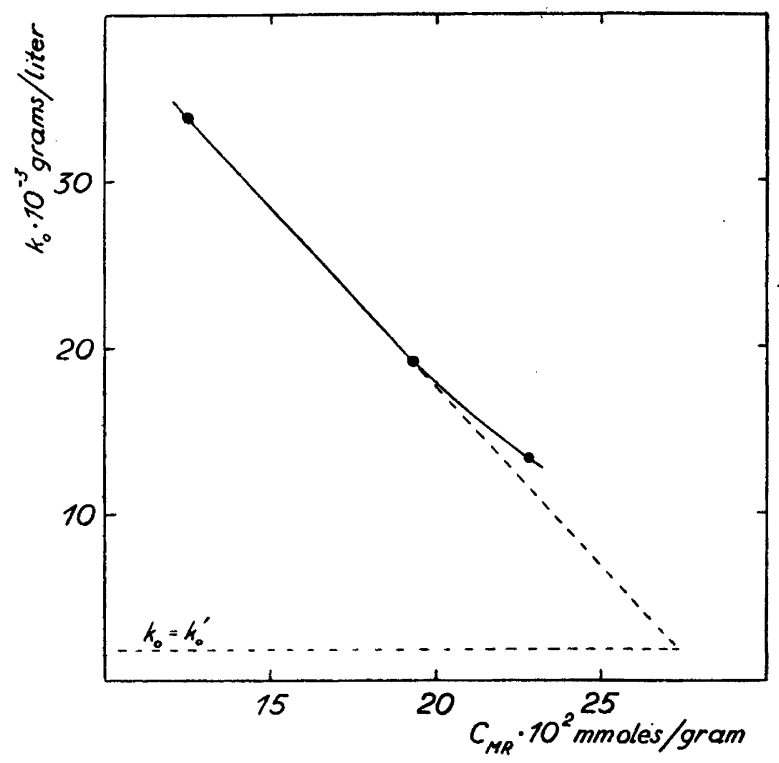

Fig. 3. The fulldrawn curve represents the relation between $k_{0}$ and $C_{\mathrm{MR}}$ for the exchange $\mathrm{Cu}^{2+}-\mathrm{Na}^{+}$on Amberlite $\mathrm{IR}-105$ at $p\left[\mathrm{H}^{+}\right]=4.9$.

$=2.9$. The quotient between the slopes of the two lines is about 30 and this is in accordance with eq. (8) if the dissociation constant of $\mathrm{HB}$ has the order of magnitude $10^{-5} \mathrm{C}$.

In order to determine the concentration $\mathrm{C}_{\mathrm{BR}}$ anew we have drawn the line $k_{0}=k_{0}^{\prime}$ in Fig. 3. The intersection of the dashed lines gives us here $\mathrm{C}_{\mathrm{BR}}$ $=0.27 \mathrm{mmoles} / \mathrm{gram}$. The agreement with the value above is satisfactory.

In Table 2 are collected the values obtained at measurements of the exchange $\mathrm{Cu}^{2+}-\mathrm{Na}^{+}$on the resin Dowex 50. We see that with this ion exchanger $k_{0}$ is quite independent of both $\mathrm{C}_{\mathrm{MR}}$ and $\mathrm{p}\left[\mathrm{H}^{+}\right]$. As emphasized by Boyd ${ }^{10}$ possibly a few carboxyl groups are introduced into a resin like Dowex 50 by the oxidation of chain-ends, but if there is in the preparation used here any fixed group $\mathrm{B}^{-}$in small concentration, forming a complex with the cupric ion, $\mathrm{C}_{\mathrm{BR}}$ evidently must be $<0.05 \mathrm{mmoles} / \mathrm{gram}$ or less than $1.3 \%$ of the exchange capacity. The value of $k_{0}=k_{0}^{\prime}$ is here $1.29 \cdot 10^{3}$ grams/liter.

Fig. 4 represents the connection between $k_{0}$ and $\mathrm{C}_{\mathrm{MR}}$ for the exchange $\mathrm{Ni}^{2+}-\mathrm{Na}^{+}$on Amberlite IR-105 (cf. Fronaeus ${ }^{6,7}$ ). At $\mathrm{p}\left[\mathrm{H}^{+}\right]=4.9$ the value of $k_{0}$ is clearly dependent upon $\mathrm{C}_{M R}$, but the variation is much smaller than that of $k_{0}$ for the exchange $\mathrm{Cu}^{2+}-\mathrm{Na}^{+}$at the same $\mathrm{p}\left[\mathrm{H}^{+}\right]$. Though $\mathrm{C}_{\mathrm{MR}}$ has been kept lower than the value of $\mathrm{C}_{\mathrm{BR}}$ determined above, the connection is 
Table 2. Determination of the mass law product $k_{0}$ for the exchange $\mathrm{Cu}^{2+}-\mathrm{Na}^{+}$on Dowex 50 at different values of $p\left[H^{+}\right]$and $C_{\mathrm{MR}}$.

\begin{tabular}{|c|c|c|c|c|}
\hline $\mathrm{p}\left[\mathrm{H}^{+}\right]$ & $\begin{array}{c}C_{\mathrm{M}}^{\prime} \\
\mathrm{mC}\end{array}$ & $\begin{array}{c}C_{\mathrm{M}} \\
\mathrm{mC}\end{array}$ & $\begin{array}{c}\mathrm{C}_{\mathrm{MR}} \cdot 10^{2} \\
\mathrm{mmole} \cdot \mathrm{g}^{-1}\end{array}$ & $\begin{array}{c}k_{0} \cdot 10^{-3} \\
1^{-1} \cdot \mathrm{g}\end{array}$ \\
\hline 4.2 & 5.28 & 3.16 & 5.38 & 1.25 \\
4.2 & 9.99 & 5.92 & 10.33 & 1.32 \\
4.2 & 15.05 & 9.08 & 15.18 & 1.30 \\
4.2 & 20.00 & 12.26 & 19.65 & 1.28 \\
3.1 & & & & \\
3.1 & 5.03 & 2.96 & 5.25 & 1.29 \\
3.1 & 10.06 & 6.00 & 10.30 & 1.30 \\
3.1 & 15.07 & 9.12 & 15.10 & 1.29 \\
\hline
\end{tabular}

not linear, showing (case $b$ ) in the theoretical treatment) that the affinity of the nickel ion for the group $\mathrm{B}^{-}$is much weaker than that of the cupric ion. This is in agreement with the results from previous investigations ${ }^{5,6}$ of the cupric and nickel acetate systems, if $\mathrm{B}^{-}$is the group- $\mathrm{COO}^{-}$. At $\mathrm{p}\left[\mathrm{H}^{+}\right]=3.0$

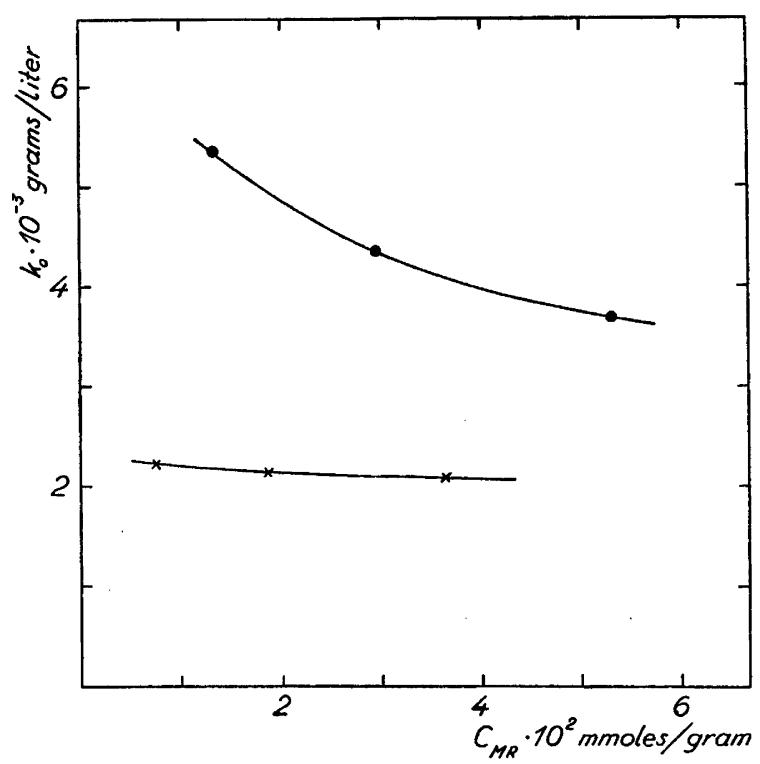

Fig. 4. The relation between $k_{0}$ and $C_{\mathrm{MR}}$ for the exchange $\mathrm{Ni}^{2+}-\mathrm{Na}^{+}$on Amberlite $\mathrm{IR}-$ 105 at $p\left[H^{+}\right]=4.9$ (O) and $3.0(\times)$.

Acta Chem. Scand. 7 (1953) No. 3 
Fig. 5. $p\left[H^{+}\right]$of the outer solution as a function of the amount $V$ of sodium hydroxide added per gram of air-dried Amberlite $I R-105$ in the hydrogen form.

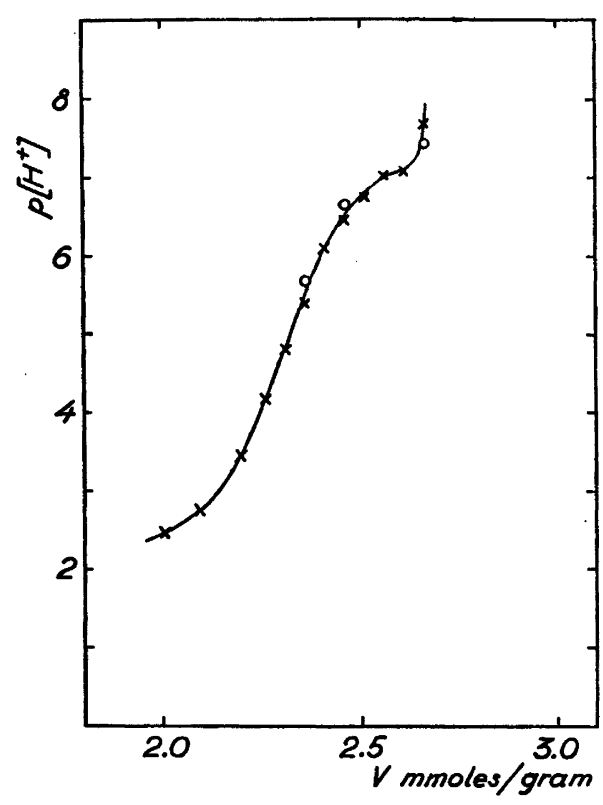

the $\mathrm{B}^{-}$-groups are practically blocked up by hydrogen ions, and the variation in $k_{0}$ is very slight.

In order to get a further proof of the existence of the group $\mathrm{B}^{-}$in Amberlite IR-105 a potentiometric $\mathrm{p}\left[\mathrm{H}^{+}\right]$-titration of the exchanger in the hydrogen form was performed.

To $0.5 \mathrm{~g}$ of the air-dried exchanger $15.0 \mathrm{ml}$ of $1 \mathrm{C}$ sodium perchlorate solution and varying amounts of sodium hydroxide solutions were added. The solution was shaken with the exchanger for twenty-four hours, and then the solution was separated and its $\mathrm{p}\left[\mathrm{H}^{+}\right]$-value was measured potentiometrically with the quinhydrone electrode. The reference electrode had the composition mentioned above. Some of the measurements were repeated with a glass electrode.

In Fig. $5 \mathrm{p}\left[\mathrm{H}^{+}\right]$of the solution is represented as a function of the amount $V$ of sodium hydroxide added per gram of the dried exchanger. Within a $V$-range surrounding the steepest part of the curve the quotient $\left[\mathrm{Na}^{+}\right]_{\mathrm{R}} /\left[\mathrm{Na}^{+}\right]$is almost constant. Then the quotient $\left[\mathrm{H}^{+}\right]_{\mathrm{R}} /\left[\mathrm{H}^{+}\right]$and the difference $\mathrm{p}\left[\mathrm{H}^{+}\right]$ $-\mathrm{p}\left[\mathrm{H}^{+}\right]_{\mathrm{R}}$ must also be approximately constant, and the $\mathrm{p}\left[\mathrm{H}^{+}\right]$-curve gives us a picture of the form of the $\mathrm{p}\left[\mathrm{H}^{+}\right]_{\mathrm{R}}$-curve.

At $\mathrm{p}\left[\mathrm{H}^{+}\right] \approx 7$ the slope has a relative minimum, indicating the presence of a weak acid group within the exchanger in the hydrogen form. At this point 
of inflection of the curve $\left[\mathrm{Na}^{+}\right]$is about $0.5 \mathrm{C}$, whereas $\left[\mathrm{Na}^{+}\right]_{\mathrm{R}}$ is very high, and thus $\mathrm{p}\left[\mathrm{H}^{+}\right]_{\mathrm{R}}\left(<\mathrm{p}\left[\mathrm{H}^{+}\right]\right)$certainly has a value between 5 and 6 . This makes it probable that $\mathrm{HB}$ is the carboxyl group, and from Fig. 5 it is evident that its concentration is very small in comparison with that of the sulphonic acid group.

Similar curves for the titration of other cation exchangers have been obtained by Gregor and Bregman ${ }^{11}$.

\section{DISCUSSION}

On account of the very good agreement between the theory given and different experimental findings we can consider it proved that the dependence of $k_{0}$ upon $\mathrm{C}_{\mathrm{MR}}$ sometimes is caused by the presence of small amounts of complex-forming structurally bound groups in the exchanger. Of course the equations are applicable also to the case that the groups have no marked proton affinity $\left(k_{c}=\infty\right)$. Thus e.g. in a resin like Dowex 50 double bonds in chainends possibly could be such groups showing great affinity for certain cations over the whole $\mathrm{p}\left[\mathrm{H}^{+}\right]$-range.

\section{SUMMARY}

The mass action law, applied to cation exchange equilibria, sometimes gives mass law products that, are very dependent on the ionic composition of the exchanger, even when variations in the rational activity coefficients cannot possibly be appreciable.

On the basis of previous measurements by the present author ${ }^{5-7}$ a theory of the variation of the mass law products is given, founded on the presumtion that small amounts of a fixed group with great affinity for certain cations are present in the exchanger.

The results from measurements of the exchanges $\mathrm{Cu}^{2+}-\mathrm{Na}^{+}$and $\mathrm{Ni}^{2+}-\mathrm{Na}^{+}$ on Amberlite IR-105 are in complete agreement with the theory and show that the groups have a great proton affinity. The presence of the groups has been proved independently by $\mathrm{pH}$-titrations. Presumably they are carboxylate groups.

Measurements of the exchange $\mathrm{Cu}^{2+}-\mathrm{Na}^{+}$on Dowex 50 show that in the preparation used of this exchanger there are no such groups with a great affinity for the cupric ion, or else their concentration is less than $1.3 \%$ of the exchange capacity. 


\section{REFERENCES}

1. Boyd, G. E., Schubert, J., and Adamson, A. W. J. Am. Chem. Soc. 69 (1947) 2818.

2. Kressman, T. R. E., and Kitchener, J. A. J. Chem. Soc. (1949) 1190.

3. Samuelson, O. Kgl. Ing. Vetenskapsakad. Handl. No 179 (1945).

4. Högfeldt, E., Ekedahl, E., and Sillén, L. G. Acta Chem. Scand. 4 (1950) 1471.

5. Fronæus, S. Acta Chem. Scand. 5 (1951) 859.

6. Fronæus, S. Acta Chem. Scand. 6 (1952) 1200.

7. Fronæus, S. Acta Chem. Scand. 7 (1953) 21.

8. Fronæus, S. Diss. Lund (1948).

9. Liebhafsky, H. A., and Winslow, E. H. J. Am. Chem. Soc. 59 (1937) 1968.

10. Boyd, G. E. Ann. Rev. Phys. Chem. II (1951) 309.

11. Gregor, H. P., and Bregman, J. I. J. Am. Chem. Soc. 70 (1948) 2370.

Received August 27, 1952.

Acta Chem. Scand. 7 (1953) No. 3 